\title{
"DARKNESS IS DIFFERENT FOR ME NOW. I KNOW ALL ITS DEPTHS AND TEXTURES”: THE PANOPTICAL GAZE IN SARAH WATERS'S AFFINITY
}

\author{
Elsa Adán HernándeZ \\ Universidad de Zaragoza \\ elsa.adan.hernandez@gmail.com
}

\begin{abstract}
The aim of this essay is to analyse Sarab Waters's novel Affinity (1999) from the perspective of the panoptical system of surveillance, based on the controlling power of the gaze, that was widely employed as a system of repression in Victorian society. It seeks to explore Milbank prison as a perfect example of Jeremy Bentham's panopticon and Michel Foucault's ideas about punishment and imprisonment. Drawing on Laura Mulvey's notion of scopophilia, the essay goes on to explore the characteristics of the interaction and mutual attraction felt by two of the main characters, with the aim of proving that the gaze can be a powerful weapon to subjugate another person. Finally, it tackles the relevance of the third protagonist, Ruth Vigers, a lady's maid whose job makes her invisible both to the readers and to other characters in the novel. The analysis shows that it is precisely her social invisibility that allows her to escape the gaze of this panoptical society and become the master puppeteer controlling everything from the shadows.
\end{abstract}

Keywords: desire, gaze, (Neo-)Victorianism, panopticon, Sarah Waters, scopophilia, surveillance. 


\title{
"DARKNESS IS DIFFERENT FOR ME NOW. I KNOW ALL ITS DEPTHS AND TEXTURES": LA MIRADA PANÓPTICA EN AFINIDAD DE SARAH WATERS
}

\begin{abstract}
RESUMEN. El objetivo de este artículo es explorar la novela de Sarah Waters Afinidad (1999), desde la perspectiva del panóptico como sistema de vigilancia y represión implementado en la sociedad victoriana, siendo el poder de la mirada una de sus principales herramientas. Principalmente, se analiza la prisión Milbank como un excelente ejemplo del panóptico diseñado por Jeremy Bentham y estudiado por las ideas de prisión y castigo de Michel Foucault. Además, la noción de escopofilia discutida por Laura Mulvey se emplea para analizar la relación y la atracción entre dos de las protagonistas, comprobando cómo la mirada puede ser una de las armas más poderosas para subyugar a otra persona. Finalmente, también se analiza la importancia de una tercera protagonista, Ruth Vigers, una sirvienta cuyo trabajo es invisible tanto para los lectores como para los demás personajes. El análisis demuestra que es precisamente esta invisibilidad la que la ayuda a escapar de la mirada de esa sociedad panóptica y convertirse en una titiritera que controla todo desde las sombras.
\end{abstract}

Palabras clave: deseo, escopofilia, mirada, (Neo-)Victorianismo, panóptico, Sarah Waters, vigilancia.

The publication of her second novel, Affinity, in 1999, one year after the publication of her debut novel, Tipping the Velvet (1998), confirmed Sarah Waters as a popular lesbian writer of historical romances. The novel was shortlisted for numerous awards and had an excellent reception among the general public and the academia. Due to its thematic complexity and stylistic and generic richness, the novel has been classified, among others, as an instance of the (neo-)Gothic, of historical romance, of Neo-Victorian fiction, and of Queer fiction. While Lucy Armitt and Sarah Gamble describe Waters's creativity in general as a "curious intermingling of passion, crime, sensationalism and social injustice" (2006: 141), Rachel Caroll acknowledges the complexity of Affinity when she asserts:

On the one hand, Affinity is a historically grounded and plausible reconstruction of marginalized women's histories: the spinster, the spirit medium, the working-class servant. [...] The past is then experienced both through the framework of revisionary feminist historiography and through the past's own conventions of representation; the novel's attempt to reconstruct a "lost" past is qualified by a consciousness of the ways in which the meanings of the past change with every attempt to "return" to it. (2006: 143)

The difficulty to ascribe Waters's fictional works to a particular genre or trend is echoed by the difficulty to pin down the author herself. As Pauline Palmer 
points out, "while claiming several different authorial identities including 'historical novelist, woman writer or just a writer', she [Waters] argues that 'it makes sense to call me a lesbian writer since I am a writer who is lesbian"” (2008: 72). Indeed, Waters's protagonists are usually lesbian women who fight against mainstream society in various historical periods ranging from the late nineteenth century to the nineteen sixties. Therefore, as Jerome de Groot explains, her novels "work backwards and forwards, commenting upon contemporary lesbian identity and the workings of sexuality in modernity" (2013: 62). As far as the historical context is concerned, it is clear that Affinity resembles Tipping the Velvet and also her third novel, Fingersmith (2002), in that they are set in the Victorian Era, and are aimed at rendering visible the stories of different female outcasts. As Armitt and Gamble state, "all three of them share a fascination with the past as spectre haunting the present, and explore the effect of this haunting on the lives and loves of dissident women" (2006: 141). More concretely, Affinity is set in London in the 1870s. It tells the story of Margaret Prior, an upper-class lady in her thirties who is still living with her mother. Pinpointed as a spinster, Margaret sees her brother Stephen and her sister Priscilla marry and make a life of their own, while she is still in the clutches of her possessive mother. After the death of her father and the unfortunate ending of the secret relation she had been leading with Helen-who gave her up in order to marry her brother-Margaret becomes so unhappy and depressed that she attempts to commit suicide. Following the doctor's recommendation to find a form of entertainment, she becomes a lady visitor at Millbank Prison, where she will meet the working-class spiritualist Selina Dawes. After several encounters, Margaret starts feeling a growing fascinated attraction towards this mysterious inmate. Thus, Selina will use her charm to escape, both from prison and from England, with her true love, the socially invisible maid Ruth Vigers.

The novel alternates diaries entries, some written by Margaret and some by Selina. At first sight, they seem to provide different perspectives on the same action, but the events recorded in each diary are dated at different times: Selina's diary is written in 1874 and that of Margaret in 1872 and 1873. As Susana Onega has pointed out, each diary belongs to a different type, reflecting their personality and social status. While Margaret's diary is a lady's journal, Selina's "extraordinarily laconic and factual entries, evincing an illiteracy that responds to her humble social position, [belong to] the type of pocket diary or memorandum created in the eighteenth century for women to keep track of daily observations and cash expenditures" (133). Margaret, a scholarly lesbian woman, shows her naivety in believing Selina, her journal showing how easily she was bewitched by her alluring spiritual tricks. By contrast, Selina's much shorter and factual entries show her working-class background, thus "serv[ing] as a counter-narrative to 
Margaret's version and vision" (Heilmann and Llewellyn 2010: 186). At the same time, however, it is Selina's entries that provide the readers with the main clues to understand what is really going on in the séances where she invokes the spirit Peter Quick, who turns out to be the puppeteer Ruth Vigers.

One of the main settings of the novel is Millbank Prison, Britain's first national penitentiary, located on the riverside of the Thames, and designed by Jeremy Bentham as a panopticon, that is, a circular prison in which cells are arranged around a single watch tower. This setting offers important clues for the understanding of the novel. As is well known, Bentham's model of the panoptical penitentiary was taken up and developed by Michel Foucault in Discipline and Punish: The Birth of the Prison (1975) as a metaphor for the powerful and sophisticated internalised coercion exerted by society on the individual through constant observation and isolation. The starting hypothesis for this essay is that a similar relation can be established between the main characters of the novel. As I will attempt to demonstrate, while Selina submits Margaret to a power-bondage relationship, she is herself in turn controlled by Ruth, who exerts constant panoptical surveyance on both the lady and the medium from her invisible position as a lady's maid. Central to this game of control and surveillance is the gaze, a key weapon in any panoptical system. Therefore, in order to explain how power relations are depicted in Affinity, I will relate some aspects of Foucault's theory of the panopticon to some important points made by Laura Mulvey on the use of the gaze in the film industry.

While exploring the birth of the modern prison by drawing on Bentham's penitentiary structure, Foucault, in Discipline and Punish, describes the panopticon as an "enclosed, segmented space, observed at every point" (1991: 197), in which vigilance is omnipresent. ${ }^{1}$ As far as the layout of the building is concerned, Foucault provides a concrete and minute description of Bentham's panopticon which is worth reproducing in full:

at the periphery, an annular building; at the centre, a tower; this tower is pierced with wide windows that open onto the inner side of the ring; the peripheric building is divided into cells, each of which extends the whole width of the building; they have two windows, one on the inside, corresponding to the windows of the tower; the other, on the outside, allows the light to cross the cell from one end to the other. All that is needed, then, is to place a supervisor in a central tower and to shut up

1 "[T]he individuals are inserted in a fixed place, in which the slightest movements are supervised, in which all events are recorded, in which an uninterrupted work of writing links the centre and periphery, in which power is exercised without division, according to a continuous hierarchical figure, in which each individual is constantly located, examined and distributed among the living beings, the sick and the dead - all this constitutes a compact model of the disciplinary mechanism" (Foucault 1991: 197). 
“DARKNESS IS DIFFERENT FOR ME NOW. I KNOW ALL ITS DEPTHS AND TEXTURES”: THE PANOPTICAL GAZE...

in each cell a condemned man [...] By the effect of backlighting, one can observe from the tower, standing out precisely against the light, the small captive shadows in the cells of the periphery. They are like so many cages, so many small theatres, in which each actor is alone, perfectly individualized and constantly visible. The panoptic mechanism arranges spatial unities that make it possible to see constantly and to recognize immediately [...] Each individual, in his place, is securely confined to a cell from which he is seen from the front by the supervisor; but the side walls prevent him from coming into contact with his companions. He is seen, but he does not see. (1991: 200)

Significantly, the first diary entry written by Margaret provides a detailed description of Millbank Prison. Some of the sentences she employs perfectly match the above definition of the panopticon. As the Director, Mr Shillitoe, slyly remarks while he is showing the building to the new Lady Visitor, "you will see the logic of the design of it" (Waters 1999: 10). Margaret describes the women's jail as "not charming. Its scale is vast, and its lines and angles, when realized in walls and towers of yellow brick and shuttered windows, seem only wrong or perverse. It is as if the prison had been designed by a man in the grip of a nightmare" (8). She then gives further details about the things she saw when walking the corridors for the first time. She admits that "the organization of the prison, of course, is so peculiar I soon grew lost" (9), and describes the building as a series of pentagons with a "hexagon-shaped building" in the middle (9). It is there that the matrons have their rooms and, of course, that the central tower is found: "the tower is set at the centre of the pentagon yards" (10). At the top of the tower there is a "bright, white, circular room, filled with windows" (10). The most obvious reference to the function of this panoptical structure comes next, when Margaret writes: "it was impossible, on entering that room, not to long to walk at once to one of its curving windows and gaze at the view beyond it [...] Now, was that not a very marvellous and terrible sight? [...] There was all the female gaol before me; and behind each of those windows was a single cell, with a prisoner in it" (11). Still, as Armitt and Gamble note, it should not be forgotten that, "though working with such historical source material in Affinity, [Waters] deliberately skews the relationship between historical fact and historical fiction, and by extension, truth and knowledge" (2006: 142). Therefore, as they go on to argue, the appearance of Millbank in such a predominant position, "carries a greater narrative significance" (143), an argument that will prove essential for the main purpose of this article.

One of the main ideas in Foucault's panopticon theory is that power is ubiquitous, and that it is exerted not only in buildings especially designed to control people, but in society at large, even, as Ariadna Serrano Bailén argues, 
in its most private circles (2008: 95). In Affinity, the panoptical gaze is not only used as a punishing and correcting tool for outlaws, but is also easily found in such an affluent Victorian home as that of the Priors. Margaret is controlled, not only by Selina-and more cunningly, by Ruth both inside and outside Millbank Prison-but also by her mother, Mrs Prior, who employs her position of power to exert constant control and surveyance on her daughter, whose deviant sexual orientation defies the patriarchal moral standards. Therefore, gainsaying Lynda Johnston and Robyn Longhurst's argument that "home spaces are a private and secure location, a locus of identity, and an area where inhabitants can escape the disciplinary practices that regulate the body in the public sphere" (in O'Callaghan 2014: 123), Margaret's home is a kind of prison, perhaps toughest than Millbank Penitentiary. Some scholars have studied this issue in depth. For example, Mark Llewellyn, in his article "Queer? I should say it is criminal!': Sarah Waters' Affinity" (2004), provides a very thorough study of panopticism in the novel, both at the prison and in society, together with a detailed analysis of the different "crimes" a woman such as Margaret would be committing from a Victorian perspective.

Describing the way in which power is exerted in the panoptical system, Janet Semple argues that "power is visible but shrouded, unverifiable and disindividualized. Those subject to power have no knowledge of it, no control over it, but are themselves the subject of knowledge and control" (1992: 115). This description is perfectly applicable to Margaret, who cannot see the plot of deceit constructed around her, blinded as she is by a love for Selina that grows into an uncontrollable state of romantic longing: "Now I have more freedom than I ever had at any time in my life, and I do only the things I always have. They were empty before, but Selina has given meaning to them" (Waters 1999: 304). Regardless of her supposedly privileged social position, Margaret becomes the main subject of the plot. This leads to another central aspect of Bentham's panopticon: the fact that criminals were considered a different kind of beings- "another order of men" - not even fully human (Semple 1993: 29). Social differences are highlighted at certain points, as for example, when one of the wardens, Miss Ridley, tells Margaret that the inmates "are not like you and me, miss [...] the sort of women who pass through here! They hold their lives very cheap..." (Waters 1999: 62). Helen expresses a similar view on the social inferiority of the inmates when, while listening to her stories about the prison, she tells Margaret: "but you cannot mean really to befriend these women? They must be thieves, and - worse!" (32; emphasis in the original). However, Margaret is both a closeted lesbian and a thirty year-old spinster-which was at the time regarded as something disgraceful-, thus doubly marginalized from the perspective of Victorian standards. This double 
“DARKNESS IS DIFFERENT FOR ME NOW. I KNOW ALL ITS DEPTHS AND TEXTURES”: THE PANOPTICAL GAZE...

marginalisation, places Margaret on a par not only with Selina but with all the women belonging to this outcast group. ${ }^{2}$ As Rosario Arias puts it in "Talking with the Dead: Revisiting the Victorian Past and the Occult in Margaret Atwood's Alias Grace and Sarah Waters' Affinity," "Selina is under constant surveillance by matrons at Millbank prison, and Margaret is subject to the control of her mother's disciplinary gaze" (2005: 98). In relation to this, Mrs Prior openly blurts out that "you [Margaret] wouldn't be ill like this [...] if you were married" (263). Even more telling is the moment in which Mrs Prior addresses Margaret as "Mrs Anybody," adding: "You are only Miss Prior. And your place-how often must I say it?-your place is here, at your mother's side" (253; emphasis in the original), making clear her outcast social position. Yet another socially disgraceful aspect of Margaret's behaviour is that, after being left by Helen, she attempted to commit suicide, a crime that would have condemned her to jail, were it not for her status as a lady.

Together with disciplinary control, the gaze is one of the most important features of the panoptical system. As Foucault explained, "Inspection functions ceaselessly. The gaze is alert everywhere" (1991: 195). In the panoptical system there is not a single moment in which prisoners could be free from the scrutinizing gaze of the jailers. This powerful weapon works without interruption, "induc[ing] in the inmate a state of conscious and permanent visibility that assures the automatic functioning of power" (1991: 201). While describing Millbank, Margaret explains that "at the side of each gate, there is a vertical iron flap which can be opened any time the matron pleases, and the prisoner viewed: they call this the 'inspection'; the women term it the eye" (Waters 1999: 23; emphasis in the original). Of course, the fact that Margaret writes "the eye" in italics enhances the importance of its function. In relation to the main point of this paper, it conveys the idea that surveillance is constant and ubiquitous, that no one can possibly escape from the controlling gaze, in this case, of a matron. In an illuminating article titled "Diary as Queer Malady: Deflecting the Gaze in Sarah Waters's Affinity" (2009/2010), Kym Brindle explores the role of the gaze in relation to the diary form, bringing to light how "[u]nseen letters escape the panoptic principle to drive both the plot and the actual love affair that plays in the shadows and sub-text of the novel" (2009/2010: Abstract). As she suggests, "the gaze and the diary work in tandem to demonstrate who reads, who writes, and who interprets and distributes textual power. The panoptic principle of the gaze is juxtaposed with the privacy of the diary to raise questions about textual manipulation and power within the author/ reader relationship" (77).

2 In Llewellyn's words, "Margaret and Selina are thus both criminals in society's eyes and are punished for breaking cultural taboos, for being unacceptably different. Although the difference is never explicitly named, women who do not conform are by definition monsters and must be watched and restrained to enforce conformity upon all women." (2004: 209; emphasis in the original). 
Starting from this premise, we can address the role of the gaze in Affinity by having recourse to Laura Mulvey's main ideas exposed in her seminal work, "Visual Pleasure and Narrative Cinema" (1999). According to Mulvey, the female image has been used in films as a way to maintain the dominant patriarchal order as woman is always considered the object of the look. Although Affinity is a piece of writing - and one about a homosexual relationship_, the same idea can be found in the novel: the female image, in this case Margaret, is constantly looked at in order to maintain the "correct" social system, especially from her mother's perspective. Margaret feels constantly scrutinised by those aligned with the social order, and she is acutely conscious of the existence of a "judgemental gaze, surmising her status and in some senses acting as an aspect of her punishment" (Llewellyn 2004: 207). When Selina asks for her help to accomplish the escape plan, she expresses her fear that both of them "would be cast off, by society" (Waters 1999: 274). The same feeling of being scrutinised arises from the constant "sharp, odd look" (200) of her mother on her, who thus becomes the ward of the house-prison. Margaret is perfectly aware of this aspect of her mother, as she proves when she decides to stop the key-hole of her room in order to gain some privacy: "it is possible to be careful, even with the chloral in me-that she might come and press her ear to the panels of my door, she would not hear me. She might kneel and put her eye to the key-hole. I have stopped it up with cloth" (224). As her allusion to the chloral makes clear, Margaret is kept under control by means of a drug treatment originally prescribed by the doctor and administered by her mother in order to cure her from her depression, that developed into a dangerous drug addiction: "and then, more laudanum, or chloral again, or morphine, or paregoric-I never tried that" (349). Margaret seems to have no escape from the accusing gaze. Consequently, "as panoptic object, under vigilance by family, staff, and doctors, it is unsurprising that Margaret seeks private communion within the confessional pages of her private diary" (Brindle 2010: 70). However, even the private sphere of her bedroom will be violated by Vigers, acting as another, more formidable because unsuspected, panoptic observer. According to Brindle, "Margaret's diary is breached to become a facilitator of surveillance that betrays its role as confidante. Mediated access to Margaret's private journal enables Selina's 'panoptical' view and allows her to violate the most private areas of Margaret's life" (2010: 74). Thus, even what Margaret believes to be absolutely private-_I said that book was like my dearest friend. I told it all my closest thoughts, and it kept them secret [...] And where can I say it, except here?" (Waters 1999: 111, 220)—is also being gazed at, adding a definitive element to the constant and omnipresent system of control exercised over Margaret in multiple forms. As she eventually realises, Margaret had also been observed at Millbank. Even if, for a moment, she believes that her visits to this prison are a form of freeing herself from the control 
she endures at home, ${ }^{3}$ she will eventually discover that she was wrong: "I would rather sit with the prisoners at Millbank than sit with Priscilla now. I would rather talk with Ellen Power, than be chided by Mother. I would rather visit Selina, than go to Garden Court to visit Helen" (176). In the prison, Selina will act as her main "ward," even if, as is discovered later on, Selina is another puppet of Ruth Vigers, who is indeed in control of everything. As Brindle puts it, "Vigers is the master of observation and the gaze" (2010: 76). Once Selina's final trick has taken place, Margaret will be looked at suspiciously by every prison ward. They will harshly interrogate her as if she knew something about Selina's escape: "When I appeared with Miss Crave they turned their eyes on me; and one of them-Mary Ann Cook, I think-made a gesture" (Waters 1999: 324).

As the novel develops, Margaret and Selina's relationship becomes more intense and intimate, and this process is perfectly shown by means of the great number of times they look at each other. As Brindle remarks, "configurations of the 'gaze' are repeated more than one hundred times throughout Waters's novel" (2010: 81). Perhaps, one of the clearest examples of Selina's control over Margaret is the episode of the locket with Selina's hair she keeps in her room. After Margaret gives up the hope of finding it, the locket suddenly appears as if she had been the victim of a trick played by the spirits. This leads Margaret to think that she is being watched by Selina: "her eyes are open, and she is looking at me" (Waters 1999: 117). These words close the diary entry of that day, the image of Selina's gaze on her resonating in Margaret's mind. As their relation advances, Margaret becomes more and more trapped by Selina's spiritualist tricks. For example, the horrifying moment when Selina talks as if she were channelling the voice of Margaret's dead: "When she looked at me now it was a kind of horror, as if she saw it all [...]. She looked at me, and her eyes had pity in them! I could not bear her gaze. I turned away from her and put my face to the bars. When I called to Mrs Jelf, my voice was shrill" (88; emphasis in the original). ${ }^{4}$ In her essay on the gaze, Laura Mulvey defines scopophilic desire as a feeling arising from the act of "looking itself as a source of pleasure" (1999: 835). This is exactly what happens in the final encounter between Margaret and Selina, when Selina gets undressed and Margaret can do nothing but stare at her beauty. In the journal, Margaret explicitly acknowledges the hypnotic effect of looking at Selina's body: "Still I gazed at Selina, not speaking-hardly breathing I think" (Waters 1999: 310), and describes Selina's act of undressing in sexually charged power-bondage terms, with her assuming the role of butch voyeur and

\footnotetext{
3 According to Serrano Bailén, this freedom is only momentary (2008: 37).

4 Since Selina "knows Margaret's secrets, [she] succeeds in inverting the power balance by turning her pitying gaze upon Margaret" (Brindle 2010: 73).
} 
Selina that of demure and coy femme: "She held herself stiffly, and kept her face turned from me-as if it hurt to have me gaze at her, yet she would suffer the pain of it for my sake" (309). Margaret's voyeuristic attitude corresponds to Mulvey's association of voyeurism with sadism. As she explains, sadism is "a battle of will and strength, victory/defeat" (1999: 840), in which, for a moment, Margaret seems to have the upper hand. This would be one of the few occasions on which the sad and depressed spinster is allowed to assume the position of powerful observer. As Beth Newman remarks, "the gaze can serve to destabilize the viewer as well as to confer mastery, especially if the gazer is caught looking by another subject who sees the gaze and perceives it as an expression of desire" (1990: 1034).

Newman's cautionary warning that the position of the gazer can be destabilised when she is caught looking is perfectly applicable to the novel, as this precisely the role of Ruth Vigers "the maid addressed by Selina as 'Ruth' and by Margaret as 'Vigers', whose presence in both diaries is rendered doubly invisible by her condition as a humble servant and an apparitional lesbian. (Onega 2017: 134-135). This double position of invisibility allows her to control the whole plot from the shadow, freely looking at and organising everything without being noticed. As Heilmann and Llewellyn explain, "while from her first visit to Millbank Margaret is aware of and sensitive to the panoptical gaze - a gaze which she realizes is also, increasingly, turned on her, both at home and in the prison-she never considers the potential dangers of the maid's gaze" (2010: 189). However, even if, as explained before, in Foucault's system, to be freed from a scrutinizing look seems impossible there is indeed a place in Millbank Prison where the inmates could be freed from the panoptical gaze: the dark cell. As Margaret acknowledges when she reaches this part of the prison, "Beyond the bars there was darkness-a darkness unbroken, so intense, I found my eyes could make no purchase on it" (181). Conceived of as a place of punishment for particularly unruly inmates, the dark room is an awe-inspiring, chilling place, that the inmates try to avoid at all costs. As Margaret notes, this room, situated at the subterranean centre of the prison, is the counterpart of the watching tower:

We took a passage [...] which, to my surprise, led away from the wards, towards the heart of Millbank - a passage which wound downwards, via spiraling staircases and sloping corridors, until the air grew even chiller and more rank, and vaguely saline, and I was sure we must be below the level of the ground [...] They [the walls] were not whitewashed, like the walls above, but rough, unfinished, and quite glistening with damp. Each was densely hung with iron - with rings and chains and fetters, and with other, nameless, complicated instruments whose purposes I could only, shuddering, guess at. (179) 
As Miss Haxby, the warder leading the way, tells Margaret, "The darkness is the punishment" (182). The fact of entering the darkness has explicit connotations of non-existence, since once "in the darks" nobody looks at you, and so, you do not exist anymore. However, taken as a metaphor for lesbian invisibility, the apparent non-existence and marginalization provided by the darks, becomes an instrument of liberation. It is her position in the dark margin of Victorian society that allows Ruth Vigers to cast a "faceless gaze" (Brindle 2010: 76) on the other characters and to freely move and progress towards the centre of society, eventually assuming the name and position of Margaret. As Heilmann and Llewellyn remark, it is the "blinding power of the subaltern's gaze" (2010: 189) that is the most dangerous, since it acts from the shadows without being noticed by anyone. This interpretation is enhanced by little hints in Selina's account in relation to Ruth and the act of gazing alerting readers about the wrongness of assuming that Ruth's social position automatically renders her powerless. For example, when Selina remarks in one of her entries that "all the time Ruth sits and watches [...] Ruth only watches, with her black eyes" (Waters 1999: 174).

As Mulvey points out, Freud "associated scopophilia with taking other people as objects, subjecting them to a controlling and curious gaze" (1999: 835; my emphasis). This idea can be easily applied to the way in which Vigers gazes at Margaret at different moments in the novel, while Margaret's gaze is inevitably turned towards her main object of desire. As her personal lady's maid, Vigers controls Margaret to the point of having access to the innermost feelings expressed in her intimate diary. Margaret's shocked discovery of her intrusion is forcefully recorded before making the decision to burn the diary and drown herself: "I seemed to see the smears of Vigers's gaze upon the pages" (Waters 1999: 348). As Margaret lets us know, "once or twice she [Vigers] has come to my room and gazed strangely at me [...] I have seen her looking curiously at the lock upon the velvet collar" (305; my emphasis). The fact that she walks softly "like a ghost" (119), equates her with an inspector. Vigers becomes an inspector since, according to Foucault, "an inspector arriving unexpectedly at the centre of the Panopticon will be able to judge at a glance, without anything being concealed from him, how the entire establishment is functioning" (1991: 204). Traditionally, the fact that Vigers lives in the attic of Margaret's house, in the most undesirable and, appositely enough, dark place, associates not only with selfhood but also with madness, as Sandra Gilbert and Susan Gubar suggest in The Mad Woman in the Attic (1979), thus enhancing the liminality of her position. However, it is precisely this ominous darker place of the house that allows Vigers to control Margaret from a position which is ironically situated on the highest storey of the house. What is more, it is precisely in this room that the most passionate and secret encounter between Selina and Ruth takes place, forcefully shattering the stiffness of 
the Victorian rules of decorum: "She had had Selina here, above my head. She had brought her past my door, and up the naked stairs-all while I sat, with my poor shielded candle. All while I waited through the long hours of the night, they were here, lying together" (Waters 1999: 341). Consequently, the reversibility of Vigers's position sets into question Foucault's assertion that "[t]he panopticon is a machine for disassociating the see/being seen dyad: in the peripheric ring, one is totally seen without ever seeing; in the central tower, one sees everything without ever being seen" (Foucault 1991: 202). Thus, we are led to consider Newman's warning that "discourses and representations are not likely to function as monolithic, total systems in which a single aspect (however powerful) cancels all internal resistance to or questioning of the status quo" (1990: 1038-9).

As this article has attempted to show, the gaze is a central aspect of Affinity. Approached from Foucault's and Mulvey's perspectives on the gaze, the novel reveals a subtle game of looks that creates a whole net of control and surveillance beyond the bricks of Millbank Prison to engulf Victorian society at large. As O'Callaghan puts it, in Affinity, "Waters illustrates how nineteenth-century domesticity reinforced normative moral imperatives to ordain strict sexual mores. Waters achieves this by paralleling the Victorian middle-class home as analogous to a prison" (2014: 125). As I have tried to demonstrate, Margaret is oppressed by society's patriarchal rules, forcefully endorsed and defenced by her mother. She is also the victim of a medical practice that sees lesbianism as a malady and prescribes drugs to combat depression. Finally, she is also oppressed, though in a subtler way, by the matrons and the inmates of the prison, who distrust her role as Lady Visitor for opposite reasons. In agreement with Foucault's premises and ideas, it seems that the despotic gaze is found everywhere, the apparent unbreakability of the system becoming the main source of ideal control. However, Vigers's invisibility allows her to subvert the strict class and sexual Victorian norms from the darkest part of the panopticon, which, ironically enough, is the one nobody dares to enter, thereby proving "how powerful the seeing but unseen woman can be" (Armitt and Gamble 2006: 158). The failure of this apparently transparent panoptical system of surveillance and punishment sets into question its irreversibility, thus destabilising the monolithic discourse of the patriarchal society it is meant to preserve.

\section{REFERENCES}

Arias Doblas, R. 2005. "Talking with the Dead: Revisiting the Victorian Past and the Occult in Margaret Atwood's Alias Grace and Sarah Waters' Affinity." Estudios Ingleses de la Universidad Complutense 13: 85-105. 
"DARKNESS IS DIFFERENT FOR ME NOW. I KNOW ALL ITS DEPTHS AND TEXTURES”: THE PANOPTICAL GAZE...

Armitt, L. and S. Gamble. 2006. "The Haunted Geometries of Sarah Waters's Affinity." Textual Practice 20.1: 141-159.

Brindle, K. 2009-2010. "Diary as Queer Malady: Deflecting the Gaze in Sarah Waters's Affinity." Neo-Victorian Studies 2.2: 65-85.

Carroll, R. 2007. "Becoming my own ghost: spinsterhood, heterosexuality and Sarah Waters's Affinity", Genders 45. Academic OneFile. <http://go.galegroup. com.proxy.lib.umich.edu/ps/i.do?id=GALE\%7CA179660939\&v=2.1\&u=lom_ umichanna\&it $=\mathrm{r} \& \mathrm{p}=\mathrm{AONE} \& \mathrm{sw}=\mathrm{w} />$. (Accessed 14 July 2018)

De Groot, J. 2013. "'Something New and a Bit Startling': Sarah Waters and the Historical Novel”, Sarah Waters. Ed. K. Mitchell. London: Bloomsbury. 56-69.

Foucault, M. 1991 (1875). Discipline and Punish: The Birth of the Prison. London: Penguin. Trans. Alan Sheridan.

Gilbert, S. M. and S. Gubar. 1979. The Mad Woman in the Attic: The Woman Writer and the Nineteenth-Century Literary Imagination. New Haven: Yale University Press.

Heilmann, A. and M. Llewellyn. 2010. "Doing It with Mirrors, or Tricks of the Trade: Neo-Victorian Metatextual Magic." Neo-Victorianism: The Victorians in the in the Twenty-First Century, 1999 - 2009. Eds. A. Heilmann and M. Llewellyn. Houndmills, Basingstoke: Palgrave Macmillan. 174-210.

Llewellyn, M. 2004. “Queer? I should say it is criminal!': Sarah Waters' Affinity (1999)." Journal of Gender Studies 13.3: 203-214.

Mulvey, L. 1999. "Visual Pleasure and Narrative Cinema." Film Theory and Criticism: Introduction Readings. Eds. L. Braudy and M. Cohen. New York: Oxford University Press. 833-44.

Newman, B. 1990. “The Situation of the Looker-On': Gender, Narration, and Gaze in Wuthering Heights." Publications of the Modern Language Association of America: 1029-1041.

O'Callaghan, C. 2014. "Sarah Waters's Victorian Domestic Spaces; or, the Lesbians in the Attic." Peer English: 122-138.

Onega, S. 2017. "Lesbian Invisibility and the Politics of Representation of the Lady and the Humble Servant in Sarah Waters' Affinity." Eds. Isabelle Brasme, JeanMichel Ganteau, and Christine Reynier. The Humble in 19th-to 21st-Centuries British Literature and Arts. Present Perfect series. Presses universitaires de la Méditerranée: Montpellier: 125-144.

Palmer, P. 2008. "'She began to show me the words she had written, one by one': Lesbian Reading and Writing Practices in the Fiction of Sarah Waters." Women: a cultural review 19.1: 69-86. 
Serrano Bailén, A. 2008. Historia e Identidad Sexual en las Novelas de Sarah Waters. Alicante: Universidad de Alicante.

Semple, J. 1992. "Foucault and Bentham: A Defence of Panopticism." Utilitas 4: 105-120.

Semple, J. 1993. Bentham's Prison. A Study of the Panopticon Penitentiary. Oxford: Oxford University Press.

Waters, S. 1999. Affinity. London: Virago Press. 